\title{
VIABILITAS SEL EPITEL RONGGA MULUT (KB CELL LINE) YANG DIPAPAR EKSTRAK ETANOL KOPI
}

\author{
Agustinus Rudolf Phyma ${ }^{1}$, Suryani Hutomo ${ }^{2}$, \\ Yanti Ivana Suryanto ${ }^{3}$, Heni Susilowati ${ }^{4}$ \\ ${ }^{1}$ Fakultas Kedokteran, Universitas Kristen Duta Wacana \\ ${ }^{2}$ Bagian Mikrobiologi, Fakultas Kedokteran, Universitas Kristen Duta Wacana \\ ${ }^{3}$ Bagian Fisiologi, Fakultas Kedokteran, Universitas Kristen Duta Wacana \\ ${ }^{4}$ Bagian Biologi Mulut, Fakultas Kedokteran Gigi, Universitas Gadjah Mada
}

Korespondensi: suryanihutomo_drg@yahoo.com

\begin{abstract}
ABSTRAK
Latar belakang: Kafein merupakan zat yang terkandung dalam kopi, teh, coklat, dan minuman bersoda. Zat dengan struktur kimia 1, 3, 7-trimethylxanthine ini merupakan derivat xanthine yang dikonsumsi hampir oleh seluruh masyarakat di seluruh dunia. Kandungan terbanyak kafein terdapat pada kopi. Penelitian terdahulu melaporkan adanya apoptosis pada osteoblas setelah dipapar kafein. Mengingat tingginya konsumsi kopi di dunia yang mengalami peningkatan 1,2\% per tahun sejak tahun 1980 hingga lebih dari $2 \%$ pada tahun 2010, perlu dilakukan penelitian untuk mengetahui efek kafein pada epitel rongga mulut yang berkontak langsung dengan kafein. Pada penelitian ini digunakan sel KB sebagai model epitel oral. Tujuan penelitian ini adalah untuk menganalisis respon sel epitel rongga mulut terhadap paparan ekstrak etanol kopi ditinjau dari viabilitas sel KB.

Metode: Sel KB (2 x 10 $10^{4}$ sel) dikultur dalam DMEM pada microplate 96 well overnight sebelum perlakuan. Sel selanjutnya dipapar dengan ekstrak etanol kopi dalam berbagai konsentrasi $(50 \mu \mathrm{g} / \mathrm{ml}, 100 \mu \mathrm{g} / \mathrm{ml}, 200 \mu \mathrm{g} / \mathrm{ml}, 400 \mu \mathrm{g} / \mathrm{ml}, 800 \mu \mathrm{g} /$ $\mathrm{ml}$ ) dan diinkubasi selama 24 jam dalam medium tanpa antibiotik. Sitotoksisitas diukur dengan menggunakan metode MTT assay. Data berupa nilai-nilai densitas optik dianalisis dengan Anava satu jalur.

Hasil: Analisis varian satu jalur terhadap nilai-nilai densitas optik pada MTT assay menunjukkan perbedaan bermakna pada $p<0,05$. Hal ini mengindikasikan bahwa ekstrak etanol kopi mampu menurunkan viabilitas sel KB setelah dipapar selama 24 jam. Analisis LSD juga menunjukkan perbedaan antara semua kelompok perlakuan, yang artinya semakin tinggi konsentrasi semakin rendah viabilitas sel $\mathrm{KB}$ yang terpapar.

Kesimpulan: Ekstrak etanol kopi menyebabkan kematian sel KB. Diperlukan studi lebih lanjut untuk mengklarifikasi tipe kerusakan sel yang diakibatkan oleh kafein.
\end{abstract}

Kata kunci: Kafein, sel KB, viabilitas sel 


\title{
THE ORAL CAVITY EPITHELIAL CELL'S VIABILITY (KB CELL LINE) EXPOSED TO COFFEE ETHANOLIC EXTRACT
}

\author{
Agustinus Rudolf Phyma ${ }^{1}$, Suryani Hutomo², Yanti Ivana Suryanto ${ }^{3}$, \\ Heni Susilowati ${ }^{4}$ \\ ${ }^{1}$ Medical Faculty of Duta Wacana Christian University \\ ${ }^{2}$ Department of Microbiology \\ ${ }^{3}$ Department of Physiology Medical Faculty of Duta Wacana \\ Christian University \\ ${ }^{4}$ Oral Biology Department, Faculty of Dentistry of Gadjah Mada University \\ Correspondence: suryanihutomo_drg@yahoo.com
}

\begin{abstract}
Background: Caffeine is a substance found in coffee, tea, chocolate, and soda drinks, with coffee known to have the highest content. Caffeine, or known chemically as 1, 3, 7-trimethylxanthine, is a derivative of xanthine consumed by almost all people around the world. Previous studies reported that there was apoptotic osteoblast exposed to caffeine. Given the high consumption of coffee among people, with increasing rate of $1.2 \%$ per year since 1980, to more than $2 \%$ in 2010, a study needs to be done to investigate the effect of caffeine on epithelial cells inside oral cavity, which make direct contact with caffeine. In this study, KB cells are used as a model of oral epithelial cells. The aim of this study was to analyze epithelial cell response to coffee ethanolic extract, observed by the viability of $K B$ cell.

Methods: $K B$ cell line $\left(2 \times 10^{4}\right.$ cells) were cultured with DMEM in microplate 96 well overnight. Cells then exposed to etanolic coffee extract in various consentrations $(50 \mu \mathrm{g} / \mathrm{ml}, 100 \mu \mathrm{g} / \mathrm{ml}, 200 \mu \mathrm{g} / \mathrm{ml}, 400 \mu \mathrm{g} / \mathrm{ml}, 800 \mu \mathrm{g} / \mathrm{ml})$ and incubated for 24 hours in medium without antibiotics. Cytotoxicity test was conducted using MTT assay. The density optic values were analized by one-way Anova.

Results: The density optic values analized by one-way Anova showed there was significantly different with $p<0,05$. It is indicated that etanolic coffee ekstract could reduce KB cells viability after 24 hours exposure. LSD analyzes also showed the differences among treatment groups, mean the higher extract concentration the lower cells viability.

Conclusion: Etanolic coffee extract could kill KB cells. It needs future study to clarify the type of cell death caused by coffee extract.
\end{abstract}

Keywords: caffein, $K B$ cell, cell viability 


\section{PENDAHULUAN}

Kafein merupakan zat yang terdapat dalam minuman yang biasa dikonsumsi oleh masyarakat seharihari. Zat ini terkandung dalam kopi, teh, coklat, dan minuman bersoda. Kafein mempunyai struktur kimia 1, 3, 7- trimethylxanthine, merupakan derivat xanthine dan dikonsumsi hampir oleh masyarakat di seluruh dunia. Kandungan terbanyak kafein terdapat pada kop, yaitu sebesar 40-180 mg/ cangkir. ${ }^{1}$ Kandungan kafein dalam teh lebih sedikit dibandingkan kopi. Black tea mempunyai kandungan yang lebih banyak dibandingkan oolong dan green tea. Satu kaleng minuman cola berisi 45,6 mg/12-oz kaleng sedangkan sebatang coklat mempunyai 6-26 mg kafein.

Konsumsi kopi di dunia mengalami peningkatan $1,2 \%$ per tahun sejak tahun 1980 hingga lebih dari $2 \%$ pada tahun 2010. ${ }^{2}$ Survei yang dilakukan Barone dan Robert pada tahun 1996 melaporkan, konsumsi kafein di dunia sehari-hari mencapai $1-2 \mathrm{mg} / \mathrm{kg} /$ hari. Konsumsi tersebut setara dengan 70$140 \mathrm{mg}$ kafein pada individu dengan berat badan 70 kg. ${ }^{3}$ Menurut Badan Pengawas Obat dan Makanan (BPOM), konsumsi kafein maksimum adalah sebesar 150 mg/hari. Batas kandungan kafein dalam minuman adalah sebesar $50 \mathrm{mg}$ per saji.

Kafein dapat menstimulasi otak dan mempengaruhi mood, meningkatkan kemampuan berpikir, menunda onset tidur, meningkatkan aliran pembuluh darah koroner, produksi urin, sekresi lambung dan metabolisme basal..$^{3,4,5,6}$ Konsumsi kafein juga dapat menurunkan faktor resiko penyakit Parkinson, menurunkan densitas mineral tulang femur pada pria usia lanjut, serta menyebabkan intrauterine growth retardation (IUGR) dan berat badan lahir rendah pada bayi. ${ }^{7}$ Penelitian lain menunjukkan bahwa kafein juga mempunyai efek sitotoksik dengan konsentrasi $10 \mathrm{ml}$ terhadap osteoblas. ${ }^{8}$ Selain itu kafein juga menurunkan viabilitas dari rat bone marrow-derived mesenchymal stromal cells (rBMSCs). Kafein akan menginduksi apoptosis pada konsentrasi $1 \mathrm{ml}$, sementara semakin tinggi konsentrasinya akan menyebabkan semakin banyak sel yang mengalami nekrosis.

Epitel oral merupakan bagian dari tubuh yang pertama kali akan terpapar langsung oleh kafein, sehingga perlu diwaspadai dosis kafein yang dapat ditoleransi olehnya. Tujuan penelitian ini adalah untuk mengetahui efek ekstrak etanol kopi terhadap epitel oral. Pada penelitian ini digunakan sel $\mathrm{KB}$ merupakan cell line yang berasal dari karsinoma epidermal mulut sebagai model epitel oral. Sel ini mempunyai kromosom marker sel HeLa.

\section{METODE PENELITIAN}

\section{Kultur sel $\mathrm{KB}$}

Sel KB diperoleh dari koleksi Lembaga Penelitian dan Pengujian Terpadu (LPPT) Universitas Gadjah Mada Yogyakarta. Sel ditumbuhkan dalam $10 \mathrm{ml}$ media penumbuh DMEM yang disuplementasi dengan FBS, penicillin $100 \mathrm{IU} / \mathrm{ml}$,streptomycin $100 \mu \mathrm{g} / \mathrm{ml}$ dan fungisone. Kultur yang telah mencapai tingkat kepadatan 80\% dipanen untuk selanjutnya dikultur kembali pada microplate 96 well sebagai subjek perlakuan yang akan dipapar dengan kafein. Sel KB disiapkan sejumlah lima replikasi untuk tiap kelompok. Sel kemudian diinkubasi pada inkubator dengan suhu $37^{\circ} \mathrm{C}$ dan $5 \% \mathrm{CO}_{2}$ selama 24 jam. 


\section{Analisis viabilitas sel KB setelah paparan berbagai konsentrasi ekstrak kopi}

Ekstrak kafein didapatkan dari biji kopi arabika yang diambil dari Temanggung, Jawa Tengah. Pembuatan ekstrak dilakukan dengan cara maserasi. Ekstrak kafein diencerkan dengan DMSO untuk didapatkan konsentrasi sebesar 0, 50, 100, 200, $400,800,1600 \mu \mathrm{g} / \mathrm{ml}$ untuk perlakuan. Sel KB $\left(2 \times 10^{4}\right.$ sel) yang telah dikultur semalam pada microplate 96 well disiapkan untuk perlakuan. Sebagian dari kultur sel KB (5 well) tidak diberi perlakuan dan dikultur dengan DMEM tanpa antibiotik sebagai kelompok kontrol negatif. Setelah paparan kafein maka sel diinkubasi pada suhu $37^{\circ} \mathrm{C}$ dalam inkubator dengan tekanan 5\% $\mathrm{CO}_{2}$ selama 24 jam.

Setelah selesai inkubasi, dilakukan MTT assay dengan menambahan larutan MTT pada kultur dilanjutkan pembacaan densitas optik (nilai absorbansi) supernatan kultur menggunakan microplate reader pada panjang gelombang 570 dengan reference wavelength $630 \mathrm{~nm}$.

\section{HASIL PENELITIAN}

Hasil penelitian menunjukkan bahwa viabilitas sel KB mengalami penurunan karena adanya paparan ekstrak kopi. Viabilitas sel berbanding lurus dengan nilai densitas optik MTT assay pada panjang gelombang $670 \mathrm{~nm}$. Nilai-nilai simpangan baku densitas optik disajikan pada Gambar 1 , sementara prosentase kematian sel $\mathrm{KB}$ juga meningkat sebanding dengan besarnya konsentrasi ekstrak etanol kopi seperti tercantum pada Gambar 2.

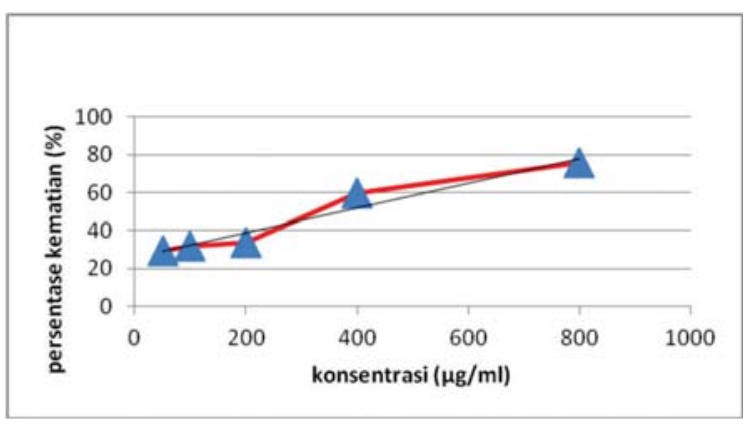

Gambar 1. Nilai densitas optik sel KB setelah paparan ekstrak kopi berbagai konsentrasi. Nilai-nilai densitas optik semakin menurun sesuai dengan peningkatan konsentrasi ekstrak kopi yang dipaparkan. Rerata dan simpangan baku merupakan hasil representatif dari tiga eksperimen.

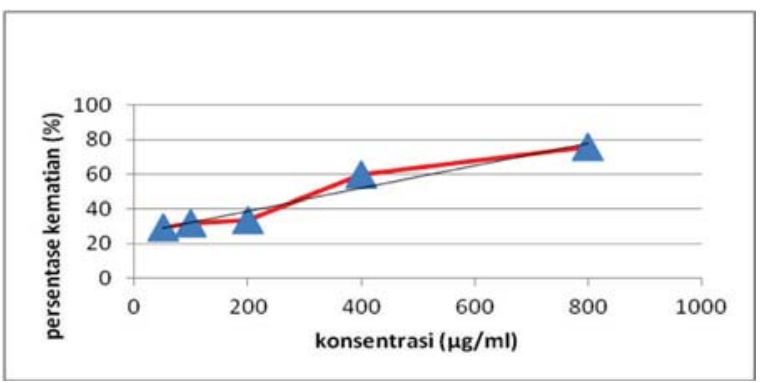

Gambar 2. Prosentase kematian sel KB pada pemberian seri dosis ekstrak kafein

Perhitungan $\mathrm{IC}_{50}$ menggunakan metode analisis regresi linear dengan sumbu $\mathrm{x}$ berupa seri konsentrasi kafein dari ekstrak etanol kopi Arabika dalam $\mu \mathrm{g} / \mathrm{ml}$ dan sumbu y berupa persentase kematian sel. Analisis regresi linear menunjukkan bahwa kafein dari ekstrak etanol kopi arabika menyebabkan kematian pada sel KB yang signifikan secara statistik dengan nilai $\mathrm{p}$ sebesar $0,005(\mathrm{p}<0,05)$.

Analisis regresi linear memberikan angka $\mathrm{IC}_{50}$ kafein dari ekstrak etanol kopi arabika sebesar 370,19 $\mu \mathrm{g} / \mathrm{ml}$. Hasil ini menandakan bahwa dibutuhkan konsentrasi kafein dari ekstrak etanol kopi Arabika sebesar 370,19 $\mu \mathrm{g} / \mathrm{ml}$ untuk membunuh $50 \%$ sel KB. 
Hubungan antara konsentrasi kafein dari ekstrak etanol kopi Arabika dan persentase kematian sel KB dapat dilihat pada gambar 3 .

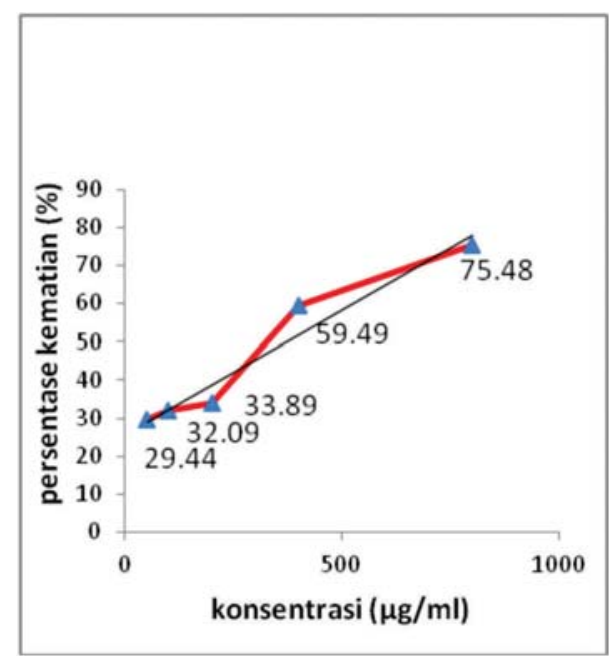

Gambar 3. Grafik persentase kematian sel KB pada seri konsentrasi kafein dari ekstrak etanol kopi Arabika
Hasil analisis normalitas SaphiroWilk terhadap nilai densitas optik menunjukkan nilai signifikansi pada kelompok $50 \mu \mathrm{g} / \mathrm{ml}, 100 \mu \mathrm{g} / \mathrm{ml}, 200 \mu \mathrm{g} /$ $\mathrm{ml}, 400 \mu \mathrm{g} / \mathrm{ml}$ dan $800 \mu \mathrm{g} / \mathrm{ml}$ berturutturut 0,$174 ; 0,175 ; 0,216 ; 0,890$ dan 0,157 . Hal ini menunjukkan bahwa data pada masing-masing kelompok terdistribusi secara normal. Sementara itu tes homogenitas menunjukkan hasil signifikansi pada $\mathrm{p}=0,051$ yang berarti data homogen. Berdasarkan hasil tes normalitas dan homogenitas maka analisis statistik dilakukan menggunakan Anava satu jalur. Hasil Anava menunjukkan nilai signifikansi $p=0,000$, yang berarti bahwa ekstrak kopi mampu menginduksi kematian sel KB (tabel 1).

Tabel 1. Nilai signifikansi densitas optik

densitas optik

\begin{tabular}{lccccc}
\hline & Sum of Squares & df & Mean Square & $F$ & Sig. \\
\hline Between Groups &, 347 & 4 &, 087 & 271,895 &, 000 \\
Within Groups &, 003 & 10 &, 000 & & \\
Total &, 350 & 14 & & & \\
\hline
\end{tabular}

\section{DISKUSI}

Hasil penelitian menunjukkan bahwa kafein dari ekstrak etanol kopi Arabika dengan konsentrasi 370,19 $\mu \mathrm{g} / \mathrm{ml}$ dapat menyebabkan kematian $50 \%$ sel KB. Penelitian terdahulu yang dilakukan oleh Kuhlman tahun 1968 melaporkan bahwa kafein menghambat pertumbuhan sel HeLa pada konsentrasi di atas $200 \mu \mathrm{g} / \mathrm{ml} .^{9}$ Penghambatan disebabkan adanya hambatan pada sintesis RNA. Hambatan ini terjadi 2-3 jam setelah pemberian kafein pada sel HeLa. Kafein juga dapat menghambat sintesis DNA setelah 48 jam perlakuan dengan konsentrasi diatas $500 \mu \mathrm{g} / \mathrm{ml}$.
Suatu senyawa dikatakan memiliki aktivitas sitotoksik apabila memiliki efek penghambatan pertumbuhan sel yang menyebabkan penurunan persentase sel yang hidup dan mengakibatkan peningkatan persentase kematian sel pada kenaikan setiap dosis. Hal ini sesuai dengan hasil dari penelitian ini dimana prosentase kematian sel KB juga meningkat sebanding dengan besarnya konsentrasi ekstrak etanol kopi.

Ada beberapa faktor yang mempengaruhi nilai $\mathrm{IC}_{50}$ suatu ekstrak tanaman seperti perbedaan cell line, spesies tanaman dan jenis pelarut yang 
digunakan. ${ }^{8}$ Kafein menunjukkan besar konsentrasi toksik yang berbeda pada cell line yang berbeda. Kafein dengan konsentrasi $10 \mathrm{mM}$ bersifat toksik terhadap sel neuroblastoma manusia SK-N-MC. ${ }^{10}$ Terhadap sel endotel vena umbilikus manusia, untuk bersifat toksik hanya dibutuhkan konsentrasi sebesar $500 \mu \mathrm{M} .{ }^{11}$ Pada penelitian ini kafein dari ekstrak etanol kopi arabika tidak menyebabkan kematian $50 \%$ sel $\mathrm{KB}$ dengan konsentrasi dibawah $200 \mu \mathrm{g} /$ ml. Hal ini dapat disebabkan nilai IC $_{50}$ juga dipengaruhi oleh ekspresi gen dan protein dari sel. Sel KB mengekspresi gen keratin, gen keratin yang diekspresikan adalah keratin 7,8,17 dan 18. Ekspresi gen keratin pada sel KB lebih rendah dibandingkan sel HeLa.

Menurut kriteria National Cancer Institute (NCI), suatu ekstrak bahan alami dengan nilai $\mathrm{IC}_{50}<30 \mu \mathrm{g} / \mathrm{ml}$ bersifat toksik. Semakin rendah nilai $\mathrm{IC}_{50}$ senyawa tersebut maka semakin toksik senyawa tersebut terhadap sel. ${ }^{12}$ Menurut Meyer, ekstrak mentah atau substansi murni suatu tanaman dikatakan berpotensi toksik apabila mempunyai nilai $\mathrm{IC}_{50}<$ $1000 \mu \mathrm{g} / \mathrm{ml} .^{5,13}$ Dari kriteria tersebut dapat disimpulkan bahwa ekstrak etanol kopi arabika dengan nilai IC${ }_{50} 370,19 \mu \mathrm{g} / \mathrm{ml}$ bersifat toksik terhadap sel KB. Mengingat kopi yang dikonsumsi sehari-hari dilarutkan dengan air, maka perlu dilakukan penelitian lebih lanjut tentang sifat sitotoksik ekstrak kopi dengan bahan pelarut air, sehingga akan dapat ditentukan dosis kopi yang dapat ditoleransi oleh sel epitel mukosa mulut. Diperlukan pula studi lebih lanjut untuk mengklarifikasi tipe kerusakan sel yang diakibatkan oleh ekstrak etanol kopi.

\section{DAFTAR PUSTAKA}

1. Chou,T. Wake Up and Smell the coffee - Caffeine, coffee and the medical consequences. The Western
Journal of Medicine. 1992; 157 : 544-553.

2. International Coffee Organization. World coffee trade; 2010. Available from : www.ico.org/trade_e. asp[Accessed 1 July 2013].

3. Nehlig, A. Dependence upon coffee and caffeine: an update. In: Nehlig A. ed. Coffee, Tea, Chocolate, and the brain. Florida : CRC press; 2004: 138.

4. Fredholm ,B.B., Battig, K., Holmen, J., Nehlig, A \& Zuartav, E. Actions of caffeine in the brain with special reference to factors that contribute to its widespread use. Pharmacological reviews, 1999; 51, 83-133. available from: phrmrev.aspetjournals.org/ content/51/1/83.long [Accessed 1 July 2013].

5. Snel, J., Tieges, Z., Lorist, M.M. Effects of caffeine on sleep and wakefulness: an update. In: Nehlig A. ed. Coffee, Tea, Chocolate, and the brain. Florida : CRC press, 2004: 22.

6. Louisa, M. \& Dewoto, H.R. Perangsang susunan saraf pusat. In: Gunawan,S. ed. Farmakologi dan terapi edisi 5. Jakarta : Departemen Farmakologi dan Terapeutik Fakultas Kedokteran Universitas Indonesia.

7. Liu, R., Guo, X., Park, Y., Huang, X., Sinha, R., Freedman, N.D., Hollenbeck, A.R. Caffeine Intake, smoking and risk of Parkinson disease in men and women. American Journal of epidemiology.2012; 175(11): 1200-1207.

8. Tsuang, HY., Sun, J.S., Chen, L.T., Sun, S.C.K., Chen, S.C. Direct effects of caffeine on osteoblastic cells metabolism: the possible causal effect of caffeine on the formation of osteoporosis. Journal of Orthopaedic Surgery and Researc; 2006; 1:7. 
9. Kuhlmann, W., Fromme, H.G., Heege, E.M., Ostertag, W. The mutagenic action of caffeine in higher organism. Cancer Research 1968; 28: 2375-2389.

10. Jang, M.H., Shin, M.C., Kang, I.S., Baik, H.H.,Cho, Y.H.,Chu, J.P., Kim, E.H., Kim, C.J. Caffeine induces apoptosis di human neuroblastoma cell line SK-N-MC. Jounal of The Korean Academy of Medical Sciences 2002; 17: 674-8.

11. Li, H.,Jin, S.Y., Son, H.J., Seo, J.H., Jeong, G.B. Caffeine- induced endo- thelial cell death and the inhibition of angiogenesis. Anatomy and Cell Biology 2013;46:57-67.

12. Itharat, A., B, Ooraikul. Research on Thai Medicinal Plants for Cancer Treatment. Advances in Medicinal Plant Research; 2007.

13. Meyer, B.N., Ferrigni, N.R., Putnam, J.E., Jacobson, L.B., Nichols, D.E., McLaughlin, J.L. Brine Shrimp; A Convenient General Bioassay for Active Plant Constituent. Journal of Medicinal Plant Research. 1982; 45: 31-3. 